\title{
Arthropod gut symbionts from the Balearic Islands: Majorca and Cabrera. Diversity and biogeography
}

\author{
by \\ Laia Guàrdia Valle ${ }^{1} \&$ Sergi Santamaria \\ Unitat de Botànica, Dept. Biol. Animal, Biol. Vegetal i Ecologia, Facultat de Ciències, \\ Universitat Autònoma de Barcelona (UAB), E-08193 Bellaterra, Spain \\ ${ }^{1}$ Corresponding Author: laia.guardia@uab.es
}

\begin{abstract}
Guàrdia Valle, L. \& Santamaria, S. 2009. Arthropod gut symbionts from the Balearic Islands: Majorca and Cabrera. Diversity and biogeography. Anales Jard. Bot. Madrid 66S1: 109-120.

This study includes a catalogue with all the current data concerning the presence of trichomycetes (sensu lato) in Majorca and Cabrera, as well as information on the biology, ecology and biogeographic implications of the insularity for each taxon of these arthropod-gut symbionts. Of the 13 species here reported, 10 are new for the Balearic Islands, including 4 Mesomycetozoan, of which 3 Eccrinales (Astreptonema gammari, Eccrinidus flexilis, Parataeniella dilatata), 1 Amoebidiales (Paramoebidium curvum) and 6 kixckellomycotina Harpellales (Genistellospora homothallica, Harpella melusinae, Smittium culisetae, S. simulii, Stachylina grandispora and St. nana); the additional 3 were previously reported elsewhere: Asellaria ligiae (Aslleariales), Legeriomyces rarus and Stipella vigilans (Harpellales), but are here included as indissoluble part of the present Balearic catalogue. All taxa are commented, illustrated and their biogeographic implications are discussed.
\end{abstract}

Keywords: biogeography, symbiosis, gut fungi, insularity, Kickxellomycotina, Mesomycetozoa, taxonomy, Zygomycota.

\section{Introduction}

The trichomycetes are eukariotic, filamentous arthropod-related obligate gut symbionts. This grouping comprises organisms that have parallelly evolved establishing their ecological niche in the arthropod gut where they nourish with the rejected food particles that pass through the intestine to be expulsed through the anus (Lichtwardt \& al., 2001; Mis-

\section{Resumen}

Guàrdia Valle, L. \& Santamaria, S. 2009. Simbiontes del intestino de artrópodos de las islas Baleares de Mallorca y Cabrera. Diversidad y biogeografía. Anales Jard. Bot. Madrid 66S1: 109120 (en inglés).

El presente estudio incluye una recopilación de todos los datos concernientes al conocimiento de los tricomicetos (sensu lato) en las islas Baleares de Mallorca y Cabrera, incluyendo un catálogo de especies y notas sobre la biología, ecología e implicaciones biogeográficas de su insularidad. De las 13 especies citadas, 10 son nuevas para las Baleares, incluyendo 4 Mesomycetozoos, de los cuales 3 Eccrinales (Astreptonema gammari, Eccrinidus flexilis, Parataeniella dilatata), 1 Amoebidiales (Paramoebidium curvum) y 6 Harpellales (kixckellomycotina) (Genistellospora homothallica, Harpella melusinae, Smittium culisetae, S. simulii, Stachylina grandispora y St. nana); aunque las 3 especies restantes: Asellaria ligiae (Aslleariales), Legeriomyces rarus y StipeIla vigilans (Harpellales) fueron citadas anteriormente, se incluyen aquí brevemente como parte del catálogo.

Palabras clave: biogeografía, simbiosis, hongos intestinales, insularidad, Kickxellomycotin, Mesomycetozoa, taxonomía, Zygomycota.

ra, 2001). The strict limitations of the gut atmosphere have shaped a convergent morphology, where the options are restricted by the space, the molting cycle of the host and the physical-chemical conditions of the environment. This morphologic convergence has been responsible for the traditional conception of the Class counting four Orders. Today, we understand the trichomycetes as an ecologically coherent group (Lichtwardt, 1986), although being manifestly polyphyletic 
(Benny \& O'Donnell, 2000; Ustinova \& al., 2000; Lutzoni \& al., 2004; Tanabe \& al., 2004; Adl \& al., 2005; Cafaro, 2005; White \& al., 2006a), with two orders, the Eccrinales and Amoebidiales currently placed within the Protozoan Mesomycetozoa (Benny \& O'Donnell, 2000; Cafaro, 2005), plus Harpellales and Asellariales, placed within the zygomicotan Kickxellomycotina (Hibbett \& al., 2007). Anyway, historical and practical motivations promote their maintenance within trichomycetes (with " $\mathrm{t}$ " to designate this polyphyletic condition or "sensu lato" treatment).

The infective capacity of Harpellales, the most diverse order of gut fungi, is restricted to the larval phases of the arthropod hosts usually associated in a commensalistic relationship. However, some dipterans can carry fungic cysts in the ovarian eggs of female adults (Labeyrie \& al., 1996; Moss \& Descals, 1986; Yeboah \& al., 1984; White \& al., 2006b). During this phase, gut fungi operate as parasites, since the reproductive capacity of the infected female (Simuliidae and Chironomidae) is affected by the inability to generate offspring from fungal-occupied eggs. After being oviposited, fungal cysts (of Harpella melusinae Léger \& Duboscq and Genistellospora bomothallica Lichtw.) will germinate to infect new larval hosts (Labeyrie \& al., 1996; Moss \& Descals, 1986; Yeboah \& al., 1984). Since the dispersive capacity of gut-fungi is mainly restricted to the dispersive capacity of their hosts, corological studies regarding the presence of this organisms in isolated environments as islands, is a good approach to infer dispersal and speciation processes.

Previously published data about Balearic trichomycete include the citation of three species (Valle, 2006; Valle \& Santamaria, 2004; Valle, 2007) which are also recompiled here (as a brief note in taxa list) as part of the catalogue for Majorca. Before these studies, knowledge of trichomycetes was inexistent for the whole Mediterranean Islands.

\section{Materials and Methods}

\section{Prospected area}

The Balearic archipelago is placed in front of the $\mathrm{Va}$ lencian and Catalan coast (Eastern Spain) and includes three main islands: Majorca, Minorca and Ibiza, the former being the larger one $\left(3640 \mathrm{~km}^{2}\right)$; Formentera (next to Ibiza) and Cabrera (next to Majorca) are smaller inhabited islands (nowadays restricted to the National Natural Park workers and visitors in the case of Cabrera), that together with another 250 islets conform the whole archipelago. The north coast of Majorca is separated about $180 \mathrm{~km}$ from Barcelona seaport. The Balearic archipelago comprises the most isolated islands in the Occidental Mediterranean. The present study is centred in $\mathrm{Ma}$ jorca, with a trichomycete citation from the minor island of Cabrera. The substrate is predominantly calcareous limestone for both prospected islands. The highest point in Majorca is Puig Major Peak (1445 m), settled in central zone of the mountain ridge called "Serra de Tramuntana", which extends through a longitude of $90 \mathrm{~km}$ next to the northern coast. Most of the rivers and streams present an irregular flow cycle, and are often superficially dried during the Mediterranean summer. During these apparently dry seasons, streams maintain a freatic activity which may provide the required humidity for the subsistence of freshwater-dependant invertebrates.

\section{Experimental methodology}

The study of arthropod-related gut symbionts requires a combination of both entomological and microbiological methodology. The entomologic methods have to be applied when collecting and identifying the hosts, while a microbiologist profile will be necessary for the extraction, processing and study of trichomycete inquilines. The methodology is explained in detail in Lichtwardt \& al., 2001. For collecting the aquatic hosts of Harpellales, mostly immature stages of Plecoptera, Ephemeroptera, Nematoceran Diptera (mainly Simuliidae, Chironomidae, Culicidae, Thaumaleidae and Ceratopogonidae), Trichoptera, and adult aquatic Isopodes (mostly with Asellarian and Eccrinid inquilines) limnology nets are required. When these hosts are found in lotic habitats, the substrate, rocks and vegetation are gently moved to incorporate the arthropods into the flow to be retained by the net, which is placed downstream. In lentic habitats the net has to be used more dynamically to capture the swimming hosts and those attached to different substrates. The potential hosts are selected using forceps and pipettes and placed into jars or plastic resealable bags to be transported to the lab, keeping the hosts alive inside an ice-cooler. Terrestrial hosts of Eccrinales and Asellariales (springtails, isopods and millipedes) are directly picked by hand, using forceps, entomologic aspirators and jars. All hosts may better be examined alive, to recover the gut symbionts in the best conditions. The hosts are dissected under a stereobinocular microscope with the help of fine forceps and needles, cleaned and separated from the gut where the trichomycetes are attached (Lichtwardt \& al., 2001). Once the symbionts are separated and settled in a clean slide with water, can be covered and observed in the scope to identify the trichomycete specimen. Photographs were taken from water-mounted slides and lactophenol-cotton- 
blue fixed slides, with an analogical camera adapted to Zeiss Henaval compound scope.

\section{Results}

\section{New records for the Balearic Islands}

The study of trichomycetes in Majorca and Cabrera has provided eleven taxa of which 8 are new for the Balearic Islands. Among the dissected arthropods, the prevalence of gut symbionts was very low, especially in the case of Harpellales, with most diversity found in aquatic Dipterans. The percentage of infected hosts (counting aquatic and terrestrial arthropods) was 3\%. We expose firstly the list with comments on the new Majorcan trichomycetes records.

\section{O. Harpellales}

Genistellospora homothallica Lichtw., Mycologia 64: 167.1972

Habitat. In the peritrophic matrix of aquatic Simuliidae (Diptera) larvae.

Known distribution. Spain, England, USA, Puerto Rico, Costa Rica, Chile and Argentina.

\section{Material examined}

SPAIN. Mallorca: Valldemossa (Torrent d'Avall), 31SDD69 [E2'37'30" N39'42'25”], prepared from Simulium sp., 3-VIII2007, microscope slides BCB-Tr1976-1979.

This species was reported from the Iberian Peninsula (Girbal \& Santamaria, 1998; Valle, 2004), although remained unknown from any Mediterranean island. The specimens collected show typical characteristics in trichospores [25-38 $\times 9-11 \mu \mathrm{m}(\bar{x}=31 \times$ $9.7 \mu \mathrm{m})$ ], with 6 appendages. The species was originally described from the USA (Lichtwardt, 1972); oddly, it has not been reported for France. Genistellospora homothallica is not common in Majorca, although is a wide-spread species in many different regions, being one of the more characteristic species from Simuliidae hosts, even in the neighbor Peninsula.

Harpella melusinae Léger \& Duboscq, Compt. Rend. Hebd. Acad. Sci. Paris 188: 951. 1929 (Figs. 1-5)

Habitat. In the peritrophic matrix of aquatic Simuliidae (Diptera) larvae.

Known distribution. Armenia, China, Dominican Republic (unpublished), France, India, Japan, Mexico (unpublished), New Zealand, Norway, Puerto Rico, Spain, USA.

\section{Material examined}

SPAIN. Mallorca: Valldemossa (Torrent d'Avall), 31SDD69
[E2'37'30" N39'42'25”], prepared from Simulium sp. larvae, 29-V2006, microscope slides BCB-Tr1817-1819. Esporles, Torrent d'Esporles, 31SDD69 [E2'37'30” N39 42'25”], prepared from Simulium sp. larvae, 5-VI-2006, without number.

This probably a cosmopolitan species, frequently present in most aquatic environments where black flies (Simuliidae) are available, living attached to their midgut perithrophic matrix. Among the species of the genus, $H$. melusinae is the most frequently reported, ranging from the Caribbean (White \& al., 2000) to the Caucasus (Nelder \& al., 2005), with recent notices of it from the Rocky Mountains (White \& al., 2006c). It was originally described from French dipterans (Léger \& Duboscq, 1929) and reported again in France by diverse authors (Léger \& Gauthier, 1935; Manier, 1950, 1970; Tuzet \& Manier, 1955). The species was observed in Norway (White \& Lichtwardt, 2004) and is known from the continental Spain (Santamaria \& Girbal, 1998), where the species has a high prevalence associated with its host. All studied specimens are in conformity with the description of $H$. melusinae, a species typically variable in the spore size [60-155 $\times 4$ $10 \mu \mathrm{m}(\bar{x}=87 \times 7 \mu \mathrm{m})$ in our specimens $]$ and shape, from coiled (Figs. 2, 4-5) to almost straight. The key character that allows its identification is the holdfast cell (small, discoid in the present species), that differentiates it from other species of Harpella.

Smittium culisetae Lichtw., Amer. J. Bot. 51: 836. 1964 (Fig. 8)

= Rubetella inopinata Manier, Rioux \& Whisler, Vie et Milieu 12: 167. 1961 [nom. inval.]

$\equiv$ Smittium inopinatum (Manier, Rioux \& Whisler) Manier, Ann. Sci. Nat. Bot. Paris 10: 565. 1970

Habitat. In the hindgut lining of aquatic Culicidae (Nematocera, Diptera) larvae.

Known distribution. Cosmopolitan, including: France, Spain, Australia, New Zealand, Japan, USA, Argentina, Brazil.

\section{Material examined}

SPAIN. Mallorca: Escorca, Mortitx stream, 31SDD91 [E2 ${ }^{\circ} 55^{\prime} 00^{\prime \prime}$ N39 $53^{\prime} 10$ ”], prepared from Culicis sp. larvae, 27-VI2003, microscope slides BCBTr1804-1806.

This is a cosmopolitan species recodred from USA, Brazil, Argentina, Australia, New Zealand, France, Japan (Lichtwardt \& al., 2001), and continental Spain (Santamaria \& Girbal, 1997). The species was originally reported from Culicidae (mosquito) larvae, but there are references indicating the presence of the species within Simuliidae and Ceratopogonidae (Licht- 
wardt, 1986). The species is characterized by the ovateellipsoidal trichospores [14-17.5 × 2.5-4 $\mu \mathrm{m}(\bar{x}=16.2 \times$ $3.3 \mu \mathrm{m})$ in our samples] with a short (ca. 1.5-2 $\mu \mathrm{m}$ ) outflared collar. The whole thallus can become fertile, with the delimitation of generative cells throughout all the branches and even main axial hypha. Smittium culisetae can be segregated from $S$. culicis by trichospore morphology, the former having the largest diameter below the middle region of the spore, the later approximately in the middle region (Manier, 1970).

Smittium simulii Lichtw., Amer. J. Bot. 51: 836. 1964 (Fig. 9)

$\equiv$ Rubetella simulii Manier, Ann. Sci. Nat., Bot., Paris 4: 737. 1963 [nom. inval.]

Habitat. In the hindgut lining of aquatic Chironomidae, Simuliidae, and rarely Culicidae and Tipulidae (Nematocera, Diptera) larvae.

Known distribution. Cosmopolitan.

\section{Material examined}

SPAIN. Mallorca: Randa, fountain and pool, 31SDD97 [E2 $55^{\prime} 00$ " N39 31'10"], prepared from Chironomidae larvae, 9IV-2006, microscope slides BCB-Tr1919-1823.

This species, initially named Rubetella simuilii Manier (nom. inval), was described from France in Simuliidae larvae (Manier, 1963). R.W. Lichtwardt observed later that it was in fact a species of the genus Smittium (Lichtwardt, 1964), reported from distant localities of the globe: from Japan, where it was observed in Simuliidae and Chironomidae (Lichtwardt \& al., 1987), from Australia and New Zealand in endemic Austrosimulium (Lichtwardt \& Williams, 1992), from Norway (White \& al., 2004) and from continental Spain (Girbal \& Santamaria, 1998). The prevalence of the species is lower than expected; the Balearic specimens were obtained from Culicidae and Chironomidae larvae. These specimens had elongateellipsoidal trichospores measuring 19-27 × 5-5.5 $\mu \mathrm{m}$ $(\bar{x}=23.2 \times 5.3 \mu \mathrm{m})$, with a collar $1.5-3.5 \times 2.3 \mu \mathrm{m}(\bar{x}$ $=2.6 \times 2.4 \mu \mathrm{m})$ of parallel or convergent margins.

Stachylina grandispora Lichtw., Mycologia 64: 193. 1972 (Fig. 6)

Habitat. In the peritrophic matrix of aquatic Chironomidae (Diptera) larvae.

Known distribution. England, Spain, Sweden, Australia, Hawaii, New Zealand, India, USA.

\section{Material examined}

SPAIN. Mallorca: Randa, Fountain and stream, 31SDD97 [E2 $\left.{ }^{\circ} 55^{\prime} 00^{\prime \prime} \mathrm{N} 39^{\circ} 31^{\prime} 10^{\prime \prime}\right]$, prepared from the hindgut lining of Diamesiinae larvae (Diptera: Chironomidae), 9-IV-2006, microscope slides BCB-Tr1819-1823.
This cosmopolitan species associated with the digestive tract of Chironomidae (Lichtwardt \& al., 2001), is reported from diverse Iberian localities (Valle, 2007), from endemic species of Chironomidae in New Zealand and Hawaii (Lichtwardt, 1986), showing its ability for long-distance dispersal and adaptability to new environments. Some of the specimens examined had slightly smaller trichospores $[27-42 \times 6-8 \mu \mathrm{m}(\bar{x}=35 \times 7 \mu \mathrm{m})]$ than usual. Actually, the species shows metric variations, especially regarding trichospore length (Lichtwardt \& al., 2001). Nonetheless, the shape of trichospores, collar [2.5-3.5 $\times$ ca. $2 \mu \mathrm{m}$ in our samples], appendage and basal cell (Fig. 6) are very constant even among different populations.

Stachylina nana Lichtw., Mycotaxon 19: 529. 1984 (Fig. 7)

Habitat. In the peritrophic matrix of aquatic Chironomidae (Diptera) larvae.

Known distribution. France, Spain, Sweden, Japan, New Zealand, Costa Rica, USA.

\section{Material examined}

SPAIN. Mallorca: Valldemossa, torrent de Valldemossa (Torrent d'Avall), 31SDD69 [E2³7'30" N3942'25”], prepared from the hindgut lining of Diamesiinae larvae (Diptera: Chironomidae), 29-V-2003, microscope slides BCB-Tr1822-1823.

Species described from material obtained in French midges (Chironomidae) (Lichtwardt, 1984). It has been reported from Japan (Lichtwardt \& al., 1987), New Zealand (Williams \& Lichtwardt, 1990), Costa Rica (Lichtwardt, 1997), Sweden (Lichtwardt, 1984) and diverse localities of USA (Lichtwardt, 1984). Santamaria \& Girbal ( 1997) also recorded it from continental Spain. Stachylina nana has a relatively short and fusiform thallus, which gives rise to a maximum of 4 trichospores. Although the trichospores of this species do not have an apparent collar, clear reminiscences of the generative cell can be observed at the proximal end of the spore. The appendage is wider at the base and attenuates to the extreme. We have widened the trichospore length range, with some smaller trichospores $[18-35 \times 6-8.5 \mu \mathrm{m}(\bar{x}=25.2 \times 7.6 \mu \mathrm{m})]$. One specimen showed a particularly small thallus which resembles St. minima M.C. Williams \& Lichtw.; this species has a basal cell that penetrated the perithrophic matrix (Williams \& Lichtwardt, 1990), and the specimen in slide Tr1822 seems to have a similar base. Anyway, spore morphology is more proximal to St. nana so it's probable that the particular basal cell may be an anomaly, as it is not very clear its penetrations to the matrix. 

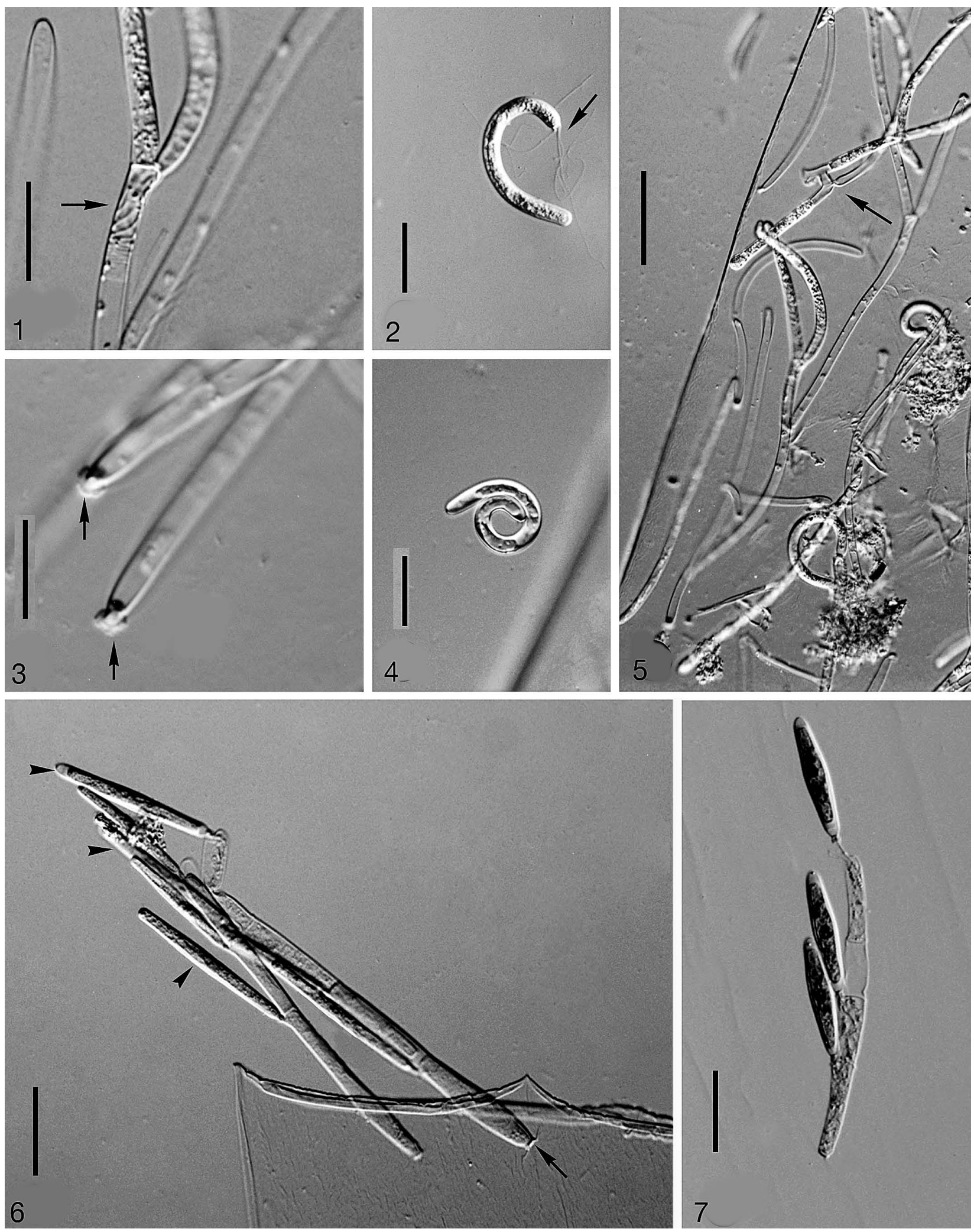

Figs.1-5. Harpella melusinae. 1. Generative cell showing the coiled trichospore appendages inside (arrow). 2. Released trichospore with appendages (arrow). 3. Basal portion of the thalli with the typical holdfast (arrow). 4. Coiled trichospore. 5. Diverse thalli within the simulid peritrophic matrix, the arrows pointing a conjugation. Fig. 6. Stachylina grandispora. Thalli with trichospores (arrowheads) and basal cell (arrow). Fig. 7. Stachylina nana. Mature thallus with trichospores. Scale bars = 25 $\mu \mathrm{m}$, Figs. 1-4,7; $50 \mu \mathrm{m}$, Figs. 5,6 . 

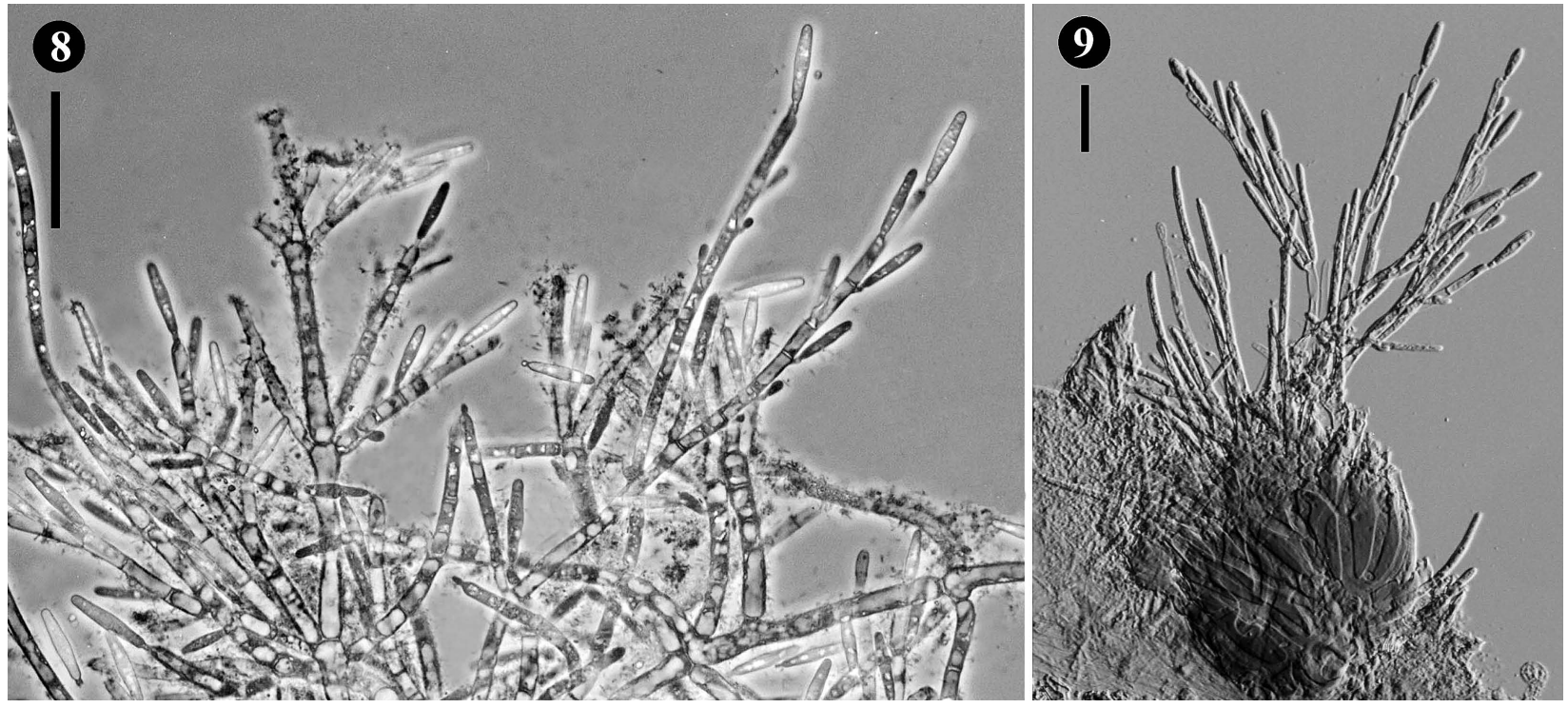

Fig. 8. Smittium culisetae. Thalli with trichospores. Fig. 9. Smittium simulii. Thalli with trichospores. Scale bars $=25 \mu \mathrm{m}$.

\section{O. Eccrinales (Mesomycetozoea)}

Fam. ECCRINACEAE

Astreptonema gammari (Léger \& Duboscq) Manier, Ann. Sci. Nat. Bot. Paris 5: 767.1964 (Fig. 10)

$\equiv$ Eccrinella gammari Léger \& Duboscq, Arch. Zoo. Exp. Gen. 75: 284. 1933

Habitat. Attached to the the hindgut lining of Gammarus sp. (Gammaridae, Crustacea).

Known distribution. Spain; France, Germany, England, USA.

\section{Material examined}

SPAIN. Mallorca: Pollença, S'Albufereta, torrent 31SEE01 [E3 $\left.05^{\prime} 20 " \mathrm{~N} 39^{\circ} 51^{\prime} 30^{\prime \prime}\right]$, prepared from the hindgut lining of Gammarus sp., 25-V-2003, microscope slides BCB-Tr1795-1796.

This is the first report of an Eccrinal species from the Balearic Islands. The specimens collected provided material with all the spore types. This Eccrinid was reported from France (Léger \& Duboscq, 1906, 1933; Poisson, 1929; Manier, 1950), Germany (Maessen, 1955), England (Moss, 1972) and USA (Lichtwardt, 1973). Léger \& Duboscq gave the name Eccrinella gammari (basionym) to this taxon (Léger \& Duboscq, 1906, 1933), but the authors did not provide a description until 1933. Finally, Manier changed the name to Astreptonema gammari Manier (1964) based on sporangiospore and thallial characters. The specimens of Majorca were found in Gammarus. Microthalli, a rare stage of this species (Manier, 1964, 1970; Lichtwardt, 1986), were observed in specimens of $A$. gammari. These thin thalli $(300 \times 1.5-2 \mu \mathrm{m})$ germinate apparently from secondary sporangiospores (2-8 nucleated, cylindrical, $25-50 \times 8-10 \mu \mathrm{m})$ produced by macrothalli, $1-2 \mathrm{~mm} \times 8-18 \mu \mathrm{m}(\bar{x}=1.4 \times$ $15.2 \mu \mathrm{m}$ ), at least it was deduced from available material. Mother cell of these microthalli is persistent (as in macrothalli) until isodiametric microspores $(2 \times 2 \mu \mathrm{m}$, uninucleated) are formed. The samples obtained in Majorcan show consistent spore morphology, coincident with the original description of the species. The uniformity is remarkable also in primary infestations spores, $22-32 \times 7-10 \mu \mathrm{m}(\bar{x}=25.8 \times 8.4 \mu \mathrm{m}), 4$-nucleated, oval with polar appendages. Size variation is more frequent in secondary infestation spores. Manier (1950, 1970) described the presence of oval spores longer than typical primary infestation spores, not obliquely arranged but longitudinally disposed in the thallus. However, we have not observed these spores, considered resistant structures (Manier, 1950, 1964, 1970; Lichtwardt, 1986).

Eccrinidus flexilis (Léger \& Duboscq) Manier, Ann. Sci. Nat. Bot. Paris 10: 469. 1970 (Fig. 11)

Eccrina flexilis Léger \& Duboscq, Compt. Rend. Hebd. Acad. Sci. Paris 142: 590. 1906

Habitat. Attached to the hindgut lining of terrestrial Glomeris sp. (Glomeridae, Diplopoda).

Known distribution. France, Spain.

\section{Material examined}

SPAIN. Mallorca: Artà, maritime slopes of Talaia Moreia, 31 SED39 [E3 $21^{\prime} 35^{\prime \prime} \mathrm{N} 39^{\circ} 46^{\prime} 40^{\prime \prime}$, prepared from the hindgut 
lining of terrestrial Glomeris sp. (Myriapoda), 4-VI-2001, microscope slides BCB-Tr1185-1187.

This species may be distributed throughout most Balearic environments, following the distribution of its host Glomeridae (Millipede). We couldn't observe the formation of primary infestation sporangiospores, or resistant spores, which usually arise just before the host starts the molting process (Lichtwardt \& al., 2001), even we kept some of the hosts in a terrarium until they started to molt, and the exuviae were examined with no success. Nonetheless, we observed secondary infestation sporangiospores (10-22 $\mu \mathrm{m}$ diameter) which provide enough data for a consistent identification, with typically oblique or perpendicular septa inside the thallial cell wall, both kinds of septa within the same individual. Holdfast morphology, characteristically with a columnar section $(17-35 \times 13-17 \mu \mathrm{m})$ $(\bar{x}=29.7 \times 15.2 \mu \mathrm{m})$, expanded in the proximal end into a basal disc $16-25 \mu \mathrm{m}$ diameter, is also of taxonomic value. The break up of the holdfast disc during the manipulation of the gut is not rare, and the disc can remain attached to the chitinous lining, showing its tight adhesion. Thalli were attached mostly at the anterior section of the hindgut lining, near the midgut section.

\section{Fam. Parataeniellaceae}

Parataeniella dilatata Poisson, Arch. Zool. Exp. Gén. 69: 205.1929 (Fig. 12)

$\equiv$ Parataeniella binucleata Poisson, Arch. Zool. Exp. Gén. 69: 207. 1929

Habitat. Attached to the hindgut lining of terrestrial isopoda Oniscidae.

Known distribution. Spain, Germany, France, USA.

\section{Material examined}

SPAIN. Mallorca: Palma, Bellver Castle Park, 31SDD78 [E2'37'35" N39'33'50"], prepared from Armadillo spp., 18-IV2001, microscope slides [Tr0695-0698]; 4-VI-2003, microscope slide BCB-Tr0684-0685. Cabrera: Cap de Llebeig, 31SDD93 [E2 $55^{\prime} 08^{\prime \prime}$ N39 09'30"], prepared from Porcellio sp., 14-VIII2004, microscope slide BCB-Tr1913-1914.

In the original publication, Poisson reported three different species: P. dilatata in the gut of Armadillo officinalis, P. intermedia within Trichoniscus roseus and P. binucleata in Porcellio laevis hindgut (Poisson, 1929). Later on, diverse authors considered that differences in these three species were not significant and Manier (1970) synonymized P. intermedia with $P$. dilatata. Lichtwardt (1986) also included P. binucleata into this taxon. The scant and variable characters in the species do not allow a narrow description, particularly regarding spore features, widely inconsistent even within a sole individual and phase of the life cycle. Parataeniella dilatata in our collections from $A r$ madillidio spp. have secondary infestation sporangiospores usually long and cylindrical, (20)40-50 × 12$13 \mu \mathrm{m}(\bar{x}=41.4 \times 12.6 \mu \mathrm{m}), 2-5$ nucleated, originated from long thalli, $300 \times(8) 12-14 \mu \mathrm{m}$, with a discret discoid holdfast. The same thalli also formed uninucleated sporangiospores (15-25 $\mu \mathrm{m}$ long), disposed in a single series. Another thallial type, 100-230 × (12)22$28 \mu \mathrm{m}(\bar{x}=196.3 \times 24.2 \mu \mathrm{m})$, was producing primary infestation sporangiospores, 1 - or 2- nucleated extruded by the apex of the holocarpic thalli. This species has been also reported from Germany (Scheer, 1976) and USA (Lichtwardt, 1986).

\section{O. Amoebidiales (Mesomycetozoa)}

As in the case of the Eccrinales, no representatives of this order were previously reported from any Mediterranean Island. We found diverse morphotypes, probably all belonging to the species Paramoebidium curvum. This species was found in diverse mayfly hosts and also in blackflies, attached to the hindgut lining. Paramoebidium spp. are not species-specific and most of them have a cosmopolitan distribution. It was present in almost all the explored localities.

\section{Previously reported species from the Balearic Islands}

Among the previously reported species, we include here a brief list of three taxa, for which the range distribution in Majorca is actualized. For further information about these species, as well as for illustrations, check the bibliographic references.

\section{O. Harpellales}

Legeriomyces rarus Lichtw. \& M.C. Williams, Canad. J. Bot. 71: 1109. 1993.

Habitat. In the hindgut linig of aquatic Caenis luctuosa (Caenidae, Ephemeroptera).

Known distribution. Australia, Tasmania, Spain.

\section{Material examined}

SPAIN. Mallorca: Sóller, Barranc de Biniaraix (Cases de L'Ofre), 31SDE70 [E2 $45^{\prime} 40^{\prime}$ N39 $45^{\prime} 50^{\prime \prime}$, prepared from Caenis luctuosa larvae, 27-V-2003, microscope slides BCB-Tr1807-1810. Valldemossa, Torrent de Valldemossa, prepared from Caenis luctuosa larvae, 30-V-2003, microscope slides BCB-Tr1813-1816.

This species was previously reported from Majorca (Valle \& Santamaria, 2004). The species was originally described from Australia, in an endemic Caenidae (Tasmanocoenis) (Williams \& Lichtwardt, 1993). In Majorca the species was found in the hindgut of $\mathrm{Cae}$ - 

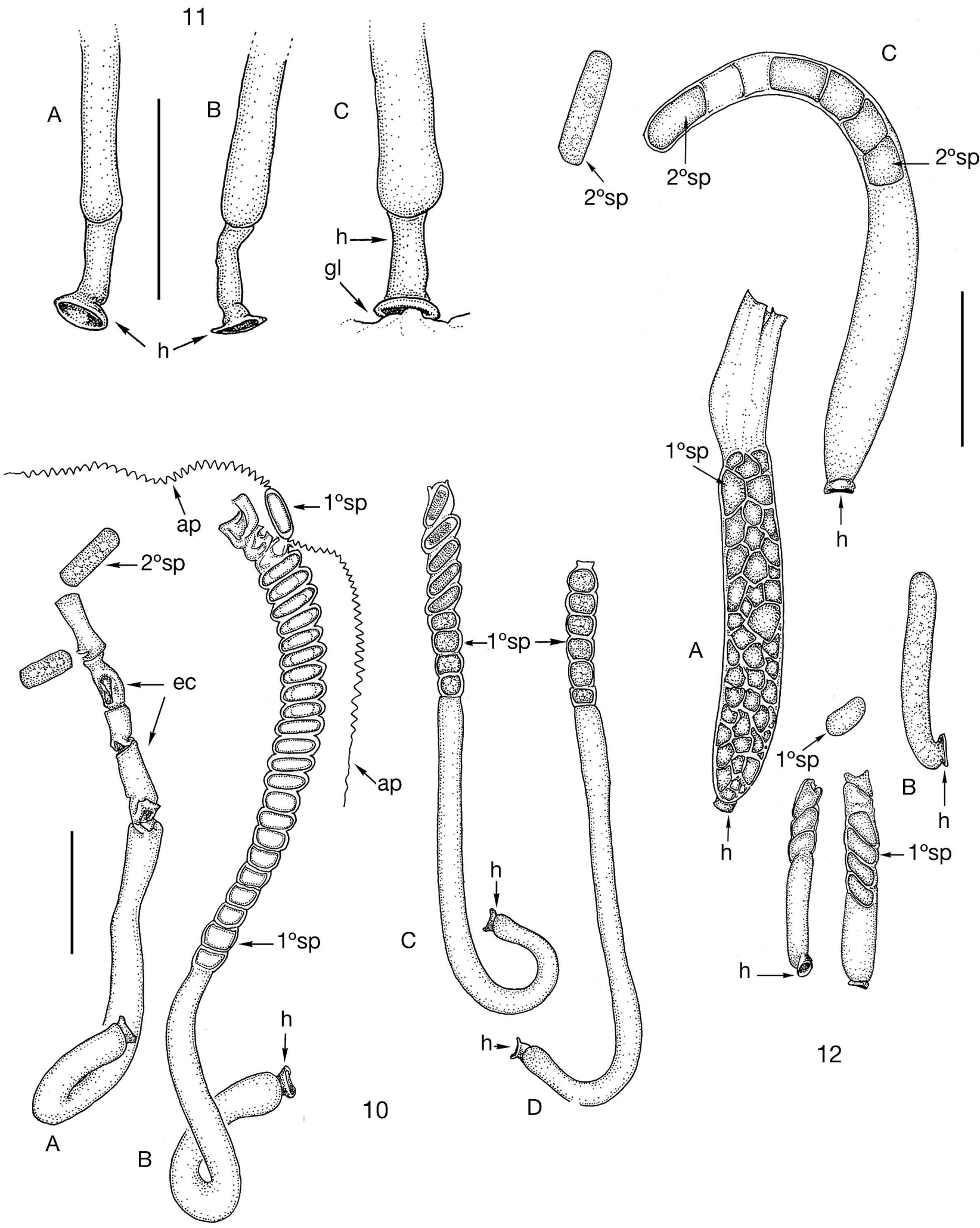

12

Figs. 10-12. Eccrinales. 10. Astreptonema gammari: A, mature thallus producing secondary sporangiospores $\left(2^{\circ} \mathrm{sp}\right)$, some of them have extruded the content and appear like empty cells (ec); B-D, diverse thalli producing primary sporangiospores $\left(1^{\circ} \mathrm{sp}\right)$ with polar appendages (ap); C, D, immature forms. 11. Eccrinidus flexilis: A-C, diverse thalli showing the basal cell; $h$, holdfast; gl, gut lining. 12. Parataeniella dilatata: A, thallus with uninucleate sporangiospores; $B$, Thalli producing primary sporangiospores $\left(1^{\circ} \mathrm{sp}\right)$; $C$, mature thallus producing secondary sporangiospores $\left(2^{\circ} \mathrm{sp}\right)$. Scale bars $=50 \mu \mathrm{m}$. 
nis luctuosa, a Mediterranean wide-spread mayfly (Valle \& Santamaria, 2004).

Stipella vigilans Léger \& Gauthier, Compt. Rend. Hebd. Acad. Sci. Paris 194: 2263. 1932

Habitat. In the hindgut lining of aquatic Simuliidae (Nematocera, Diptera) larvae.

Known distribution. France, England and Spain.

\section{Material examined}

SPAIN. Mallorca: Santa Maria del Camí, torrent de Coanegre, 31SDD79, prepared from Simulium sp, 27-V-2003, microscope slide BCB-Tr1802. Sóller, Biniaraix, torrent de l'Ofre, 31SDE70, prepared from Simuliidae, 29-V-2003, microscope slides BCBTr1811-1812. Valldemossa, torrent de Valldemossa (Torrent d'Avall), 31SDD69 [E2 $37^{\prime} 30^{\prime \prime} \mathrm{N} 39^{\circ} 42^{\prime} 25^{\prime \prime}$ ], prepared from Simulium sp, 30-V-2003, microscope slides BCB-Tr1817-1821, BCB-Tr1825. Puigpunyent, Sa Riera, 31SDD58 [E2³2'25” N39³6'50"], prepared from Prosimulium sp., 13-IV-2006, microscope slides BCB-Tr1927.

Stipella vigilans was originally described from the French Alps in the hindgut of Simuliidae, together with the protozoan Paramoebidium sp. (Léger \& Gauthier, 1932). This species was also reported from the Balearic Islands (Valle, 2007), and the specimens collected from Majorca show basically the same characteristics as of other continental European specimens.

\section{O. Asellariales}

Asellaria ligiae Tuzet \& Manier ex Manier, Ann. Sci. Nat. Bot. Paris 9: 93.1968

$\equiv$ Asellaria ligiae Tuzet \& Manier, Ann. Sci. Nat. Zool. Paris 12: 15-23. 1950 [nom. inval.]

Habitat. In the hindgut lining of marine (sea-shore zone) Ligia italica (Isopoda, Aseliidae).

Known distribution. Cosmopolitan.

\section{Material examined}

SPAIN. Mallorca: Pollença, S'Albufereta, 31SEE01 [E305'20" N39 51'30"], prepared from Ligia italica, 25-V-2003, microscope slides BCB-Tr1797-1798.

Species previously reported from the Balearic Islands, in the hindgut lining of the sea-shore isopod Ligia italica Fabr. (Ligidae) (Valle, 2006). The species is world-wide distributed as most marine gut fungi inhabiting cosmopolitan hosts.

\section{Discussion}

Among the species reported in this preliminary study, it's remarkable the prevalence of Harpellales associated to Nematoceran (lower Dipterans) hosts of the families Simuliidae (black-flies), Chironomidae (midges and blood-worms) and Culicidae (mosqui- toes). In fact, a sole harpellid species, Legeriomyces rarus, was reported from a non-dipteran host, in Caenis luctuosa (Ephemeroptera: Caenidae), which is widely dispersed in Europe and North Africa (Laurasian-Godwanan distribution; Jacob, 2003). Nonetheless, diverse specimens of mayflies (Ephemeroptera: Baetidae and Caenidae) and stoneflies (Plecoptera: Leuctridae) were analyzed in different lowland and upland localities, showing no trichomycetes in their guts. Currently, some wide-spread Holarctic species common in Peninsular localities (Valle, 2004), such as Legeriomyces ramosus Pouzar (in Baetidae), or Simuliomyces microsporus Lichtw. (both in Simuliidae) have not been observed from Majorca, although their hosts are common in the explored Balearic streams. All the specimens of the present catalogue can be considered among characteristically widespread species (at least with Holarctic distribution), except for the case of Stipella vigilans, apparently restricted to Western Europe (France, England, Iberian Peninsula and Balearic Islands), and Legeriomyces rarus which shows an Ibero-Balearic and Australian disjunct distribution (Williams \& Lichtwardt, 1993; Valle \& Santamaria, 2004). This species was described from Australia, in the digestive tract of the endemic Caenidae Tasmanocoenis (Williams \& Lichtwardt, 1993). The distribution of the species has to be considered cautiously for the scant data about trichomycetes in vast regions, showing this apparently disrupted occupancy, when the species is probably more throughout distributed (Valle \& Santamaria, 2004). The low prevalence of Balearic Harpellales associate to Ephemeroptera and Plecoptera (compared to the neighbour continent) may be explained by the low vagility of this insects added to the absence of gut fungi diaspores transported by the flying adults, confining the infective capacity of the fungus to the nymphal phases of the hosts. Then, if an ancient infection of Harpellales was not settled within the originary entomofauna which was aisled about 150 thousand years ago (when the Tirrenic beaches were shaped and the rising Mediterranean Sea level aisled the Balearic archipelago), the probability of posterior Harpellales colonization from the continent is very low, even considering the possibility of transoceanic adult mayfly movements, as noted in recent studies (Monaghan \& al., 2005). Even considering that a harpellid prevalence comparable to that in the landmass was initially established, fragmented islands show a common disharmony concerning species composition in relation to the proximal continent. Discordance results firstly from the species sampling that were on the mainland landmass prior to sea level ascend (Gillespie \& Roderick, 2002). After fragmenta- 
tion, this produces an impoverishment (or relaxation) that may be accentuated by subsequent extinction and failure of the species to recolonize (Powell \& Wagner, 1993; González, 2000; Desmet \& Cowling, 2004). Another factor to explain the hosts/inquiline impoverishment may be related with climatic variations through time, which could affect the composition and occurrence of aquatic insects, dropping the initial diversity to few species with better adaptative plasticity (Gillespie \& Roderick, 2002). It has been proved by paleopalinologic studies that Majorca had, in a relatively proximal Holocene epoch $(8000-6000$ years $\mathrm{bp}$ ), a more humid clime which allowed the prevalence of deciduous humid forests (Fagus sylvatica) and riparian communities (Pérez-Obiol \& al., 2003), being probably more favourable to aquatic invertebrates and related gut fungi, which likely declined during subsequent registered climatic changes that lead to the failure of such humid vegetation and the transition to the actual xeric vegetation and scant intermittent riparian formations (Pérez-Obiol \& al., 2000, 2003).

By the other hand, we noted that most Balearic Harpellales were found in Dipteran hosts where diverse gut fungi counting $H$. melusinae, $G$. homothalli$\mathrm{ca}$ and Smittium spp. have proved the capacity to travel with female adults as ovarian fungal cysts that can be posteriorly ovoposited (Labeyrie \& al., 1996; Moss \& Descals, 1986; Moss, 1998; Yeboah \& al., 1984) to infest new larval hosts in distant places, specially when exogenic forces allow the transportation, as strong air currents (de Queiroz, 2005). Moreover, it is probable that many other species of Dipteran-associated Harpellales have the capacity to travel with their adult host inside the ovary (Lichtwardt \& al., 2001; Reeves, 2004) or by other instances, although phoretic dispersion is not expected to be a reliable system for spores adapted to disperse short distances outside the host, nor for the need of close approximation to specific larval populations (Lichtwardt \& al. 2001). Thus, Harpellales associated to Simuliidae and Chironomidae might have the capacity to spread longer distances inside flying adult hosts, what may explain their prevalence in isolated freshwater environments. This has been supported by the previously recorded presence of dipteran-related species (such as Stachylina grandispora, Smittium culisetae and S. simulii, among others) in small containers (jars, cans, etc.), headwaters and islands (Lichtwardt \& al., 2001; Strongman, 2007), where the fungus could never arrive by means of larval host dispersal.

Despite fresh-water isopods have been found in continental localities of Spain carrying Asellaria species (Valle, 2006), none of diverse examined isopods from streams of Majorca was infected with Asellariales.

The presence of endosymbiotic organisms within terrestrial arthropods (Isopoda: Oniscidae and Diplopoda: Glomeridae) in isolated environments seems to be derived from the facility of these organisms to perform trans-maritime surface trips on floating debris and vegetation, which are specially abundant after raining periods, transported by river currents to the open sea with many different organism being carried on them. In the case of continental islands, as the Balearic archipelago, non-flying terrestrial arthropods may have predominantly a continental origin by vicariance, without excluding more recent dispersion phenomena from proximal coast lines. Gut symbionts in these arthropods may have the same origin, as the spores have not been proven to have the ability to disperse long distances out of their hosts.

We may need more information about trichomycetes in islands to determinate the origin of such organisms. Nonetheless, dispersion in the case of Balearic Harpellales (even being an island of continental origin) seems to be more important than vicariance as indicated by the cosmopolitan character and dispersing capacity of the reported taxa.

In Cabrera Island, trichomycetes fauna was restricted to the presence of Eccrinales associated to terrestrial isopods, as the island has very few reservoirs of freshwater, especially lotic environments where most of the potential trichomycetes hosts are found.

\section{Acknowledgements}

The authors wish to express their gratitude to the members of the IMEDEA (Mediterranean Institute for Advanced Studies) for their pleasant reception and lab facilities during some of the surveys in Majorca, especially to Enric Descals who kindly sheltered the author in his lab. Also to Llorenç Sáez for his help in the hosts' recollection; I appreciate indeed his experience on the Island geography. We are also indebt with the personnel in the Cabrera $\mathrm{Na}-$ tional Park for their nice reception and comfortable sheltering in the research cottages, also for their help in maritime transportation. This research was financed by MCYT and FEDER (REN2002-04068-C02-02 “Flora Micológica Ibérica VI”).

\section{References}

Adl, S.M., Simpson, A.G., Farmer, M.A., Andersen, R.A., Anderson, O., Barta, J.R., Bowser, S.S., Brugerolle, G., Fensome, R.A., Fredericq, S., James, T.Y., Karpov, S., Kugrens, P., krug, J., Lane, C.E., Lewis, L.A., Lodge, J., Lynn, D.H., Mann, D.G., Mccourt, R.M., Mendoza, L., Moestrup, L.Ø., Mozley-Standridge, S.E., Nerad, T.A., Shearer, C.A., Smirnov, A.V., Spiegel, F.W. \& Taylor, M.F. 2005. The New Higher Level Classification of Eukaryotes with Emphasis on the Taxonomy of Protists. Journal of Eukaryota Microbiology 52: 399-451.

Benny, G.L. \& O’Donnell, K. 2000. Amoebidium parasiticum is a protozoan, not a Trichomycete. Mycologia 92: 1133-1137. 
Cafaro, M.J. 2005. Eccrinales (Trichomycetes) are not fungi, but a clade of protists at the early divergence of animals and fungi. Molecular Phylogenetic Evolution 35: 21-34.

De Queiroz, A. 2005. The resurrection of oceanic dispersal in historical biogeography. Trends in Ecology and Evolution 20: 68-73.

Desmet, P. \& Cowling, R. 2004. Using the species-area relationship to set baseline targets for conservation. Ecology and Society 9: 11. [online] URL: http://www.ecologyandsociety.org/ vol9/iss2/art11/

Gillespie, R.G. \& Roderick G.K. 2002. Arthropods on Islands: Colonization, Speciation and Conservation. Annual Review of Entomology. 47: 595-632.

Girbal, J. \& Santamaria, S. 1998. Trichomycetes (Fungi, Zygomycotina) comensals de larves de Simuliidae (Diptera) a la Península Ibèrica. Acta Botanica Barcinonensia 45: 49-56.

González, A. 2000. Community relaxation in fragmented landscapes. The relation between species richness, area and age. Ecology letters 3: 441-443.

Hibbett, D.S., Binder, M., Bischoff, J.F., Blackwell, M., Cannon, P.F., Eriksson, O.E., Huhndorf, S., James, T., Kirk, P.M., Lücking, R., Lumbsch, T., Lutzoni, F., Matheny, P.B., Mclaughlin, D.J., Powell, M.J., Redhead, S., Schoch, C.L., Spatafora, J.W., Stalpers, J.A., Vilgalys, R., Aime, M.C., Aptroot, A., Bauer, R., Begerow, D., Benny, G.L., Castlebury, L.A., Crous, P.W., Dai Y. Cheng, Gams, W., Geiser, D.M., Griffith, G.W., Gueidan, C., Hawksworth, D.L., Hestmark, G., Hosaka, K., Humber, R.A., Hyde, K., Ironside, J.E., Kõljalg, U., Kurtzman, C.P., Larsson, K. Henrik, Lichtwardt, R.W., Longcore, J., Miadlikowska, J., Miller, A., Moncalvo, J. Marc, Mozley-Standridge, S., Oberwinkler, F., Parmasto, E., Reeb, V., Rogers, J.D., Roux, C., Ryvarden, L., Sampaio, J., Paulo, Schüssler, A., Sugiyama, J., Thorn, R.G., Tibell, L., Untereiner, W.A., Walker, C., Wang, Z., Weir, A., Weiss, M., White, M.M., Winka, K., Yao, Y., Jian \& Zhang, N. 2007. A higher-level phylogenetic classification of the Fungi. Mycological Research 111: 509-547.

Jacob U. 2003. Africa and its Ephemeroptera: Remarks from a biogeographical view. In: Gaino E. (ed.), Research update on Ephemeroptera E Plecoptera: 317-325. Università di Perugia. Perugia, Italy.

Labeyrie, D.P., Molloy, R.W. \& Lichtwardt, R.W. 1996. An investigation of Harpellales (Trichomycetes) in New York state blackflies (Diptera: Simuliidae). Journal of Invertebrate Patho$\operatorname{logy}$ 6: 293-298.

Léger, L. \& Duboscq, O. 1906. L'évolution des Eccrina des Glomeris. Comptes Rendus Hebdomadaires des Séances de l'Académie des Sciences de Paris 142: 590.

Léger, L. \& Duboscq, O. 1929. Harpella melusinae n. g. sp. Entophyte eccriniforme parasite des larves de Simulie. Comptes Rendus Hebdomadaires des Séances de l'Académie des Sciences de Paris 188: 951-954.

Léger, L. \& Duboscq, O. 1933. Eccrinella (Astreptonema?) gammari Lég. et Dub. Eccrinide des Gammares d'eau douce. Archives de Zoologie Expérimentale et Générale 75: 283-292.

Léger, L. \& Gauthier, M. 1932. Endomycètes nouveaux des larves aquatiques d'Insectes. Comptes Rendus Hebdomadaires des Séances de l'Académie des Sciences de Paris 194: 2262-2265.

Léger, L. \& Gauthier, M. 1935. La spore des Harpellacees (Léger et Duboscq), Champignons parasites des Insectes. Travaux $d u$ Laboratoire d' Hydrobiologie et de Pisciculture de l' Université de Grenoble 27: 3-6.

Lichtwardt, R.W. 1964. Axenic culture of two new species of branched Trichomycetes. American Journal of Botany 51: 836842.

Lichtwardt, R.W. 1972. Undescribed genera and species of Harpellales (Trichomycetes) from the guts of aquatic insects. Mycologia 64: 167-197.
Lichtwardt, R.W. 1973. The Trichomycetes: what are their relationships? Mycologia 65: 1-20.

Lichtwardt, R.W. 1984. Species of Harpellales living within the guts of aquatic Diptera larvae. Mycotaxon 19: 529-550.

Lichtwardt, R.W. 1986. The Trichomycetes: Fungal Associates of Arthropods. Springer-Verlag, New York. 343 pp.

Lichtwardt, R.W. 1997. Costa Rican gut fungi (Trichomycetes) infecting lotic insect larvae. Revista de Biología Tropical 45: 13391383.

Lichtwardt, R.W., Kobayasi, Y. \& Indoh, H. 1987. Trichomycetes of Japan. Transactions of the Mycological Society of Japan 28: 359-412.

Lichtwardt, R.W. \& Williams, M.C. 1992. Tasmanian Trichomycete gut fungi in aquatic insect larvae. Mycologia 84: 384-391.

Lichtwardt, R.W., Cafaro, M.J., \& White, M.M. 2001. The Trichomycetes: Fungal associates of arthropods. Revised edition, published on the Internet: www.nhm.ku.edu/fungi/

Lutzoni, F., Kauff F., Cox C.J., McLaughlin, D., Celio, G., Dentinger, B., Padamsee M., Hibbett D.S., James, T.Y., Baloch, E., Grube, M., Reeb V., Hofstetter, V., Schoch, C., Arnold, A.E., Miadlikowska, J., Spatafora, J., Johnson, D., Hambleton, S., Crockett, M., Shoemaker, R., Sung, G.-H., Lücking, R., Lumbsch, T., O’Donnell, K., Binder, M., Diederich, P., Ertz, D., Gueidan, C., Hansen, K., Harris, R.C., Hosaka, K., Lim, Y.-W., Matheny, B., Nishida, H., Pfister, D., Rogers, J., Rossman, A., Schmitt, I., Sipman, H., Stone, J., Sugiyama, J., Yahr, R., \& Vilgalys, R.. 2004. Assembling the fungal tree of life: progress, classification, and evolution of subcellular traits. American Journal of Botany 91: 1446-1480.

Maessen, K. 1955. Die zooparasitären Eccrinidales. Parasitologische Schriftenreibe 2: 1-129.

Manier, J.-F. 1950. Recherches sur les Trichomycètes. Annales des Sciences Naturelles Botanique Série 11, 11:53-162.

Manier, J.-F. 1963. Trichomycètes de larves de Simulies (Harpellales du proctodeum). Annales des Sciences Naturelles Botanique, Paris, Série 12, 4: 737-750.

Manier, J.-F. 1964. Nouvelle contribution à l'étude des Trichomycètes (Eccrinales parasites d'Amphipodes). Annales des Sciences Naturelles Botanique, Paris, Série 12, 5: 767-772.

Manier, J.-F. 1970. Trichomycètes de France. Annales des Sciences Naturelles Botanique, Paris, Série 12, 10: 565-672.

Misra, J.K. 2001. Trichomycetes, fungi associated with arthropods: an introduction and state-of-the-art in the tropics. In: Misra, J.K. \& Horn, B.W. (eds.), Trichomycetes and other fungal groups: 3 13. Science Publishers, Inc., Enfield, New Hampshire, USA.

Monaghan, M.T., Gattolliat, J.L, Sartori, M., Elouard, J.M., James, H., Derleth, P. \& Glaizot, O. 2005. Trans-oceanic and endemic origins of the small minnow mayflies (Ephemeroptera, Baetidae) of Madagascar. Proceedings of The Royal Society B-Biological Sciences 272: 1829-1836.

Moss, S.T. 1972. Occurrence, cell structure and taxonomy of the Trichomycetes, with special reference to electron microscope studies of Stachylina. Ph. D. Dissertation, University of Reading. 340 pp.

Moss, S.T. 1976. Formation of the trichospore appendage in Stachylina grandispora (Trichomycetes). In: Fuller, R. \& Lovelock, D.W. (eds.), Microbial Ultrastructure. The Use of the Electron Microscope: 279-294 Academic Press, New York.

Moss, S.T. 1998. Harpellales (Trichomycetes); mycobionts of Insecta. Botanical Journal of Scotland 50: 137-152.

Moss, S.T. \& Young, T.W.K. 1978. Phyletic considerations of the Harpellales and Asellariales (Trichomycetes, Zygomycotina) and the Kickxellales (Zygomycetes, Zygomycotina). Mycologia 70: 944-963.

Moss, S.T. \& Descals, E. 1986. A previously undescribed stage in the life cycle of Harpellales (Trichomycetes). Mycologia 78: 213-222. 
Nelder, M.P., McCreadie, J.W., \& Beard, C.E. 2005. Laboratory investigations of trichomycete prevalence, abundance, and fecundity in a Smittium-simuliid model. Mycologia 97: 338-345. Mycologia 70: 944-963.

Perez-Obiol, R., Yll, E.I., Pantaleón Cano, J. \& Roure, J.M. 2000. Evaluación de los impactos antrópicos y los cambios climáticos en el paisaje vegetal de las Islas Baleares durante los últimos 8000 años. In: Guerrero, V.M. \& Gornés, S. (Coords.): Colonización bumana en ambientes insulares. Interacción con el medio y adaptación cultural. Universitat de les Illes Balears: 444454. Palma de Mallorca. Spain.

Perez-Obiols, R., Sáez, L. \& Yll, E.I. 2003. Veststigis florístics postglacials a les Illes Balears i dinàmica de la vegetació holocènica. Orsis 18: 77-94.

Poisson, R. 1929. Recherches sur quelques Eccrinides parasites de Crustacés Amphipodes et Isopodes. Archives de Zoologie Expérimentale et Générale 69: 179-216.

Powell, J.A. \& Wagner, D.L. 1993. The microlepidoptera fauna of Santa Cruz Islands is less depauperate than that of butterflies and larger moths. In: Halvorson, W.L. \& Maender, G.J. (eds.), Third California Islands Symposium: Recent advances in Research on the California Islands: 449-464. Santa Barbara.

Reeves, W.K. 2002. Trichomycetes in the middle of nowhere (the Crozet Islands story). Entomological Society of America Annual Meeting (Abstract D0626).

Reeves, W.K. 2004. Temporal distribution of Smittium culisetae in a wild population of Wyeomyia smithii from pitcher plants. $M y$ cologia 96: 1233-1235.

Santamaria, S. \& Girbal, J. 1997. Contribución al conocimiento de los Trichomycetes (Fungi, Zygomycotina) ibéricos. Anales del Jardín Botánico de Madrid 55: 219-223.

Santamaria, S. \& Girbal, J. 1998. Two new species of Orphella from Spain. Mycological Research 102: 174-178.

Scheer, D. 1976. Parataeniella mercieri (Poisson) (Trichomycetes, Eccrinales) und ihre Wirte in der Deutschen Demokratischen Republik. Archiv für Protistenkunde 118: 202-208.

Strongman, D.B. 2007. Trichomycetes in aquatic insects from Prince Edward Island, Canada. Canadian Journal of Botany 83: 949-963.

Tanabe, Y., Saikawa, M., Watanabe, M.M. \& Sugiyama, J. 2004, Molecular phylogeny of Zygomycota based on EF-1 and RPB1 sequences: limitations and utility of alternative markers to rDNA. Molecular Phylogenetics and Evolution 130: 438-449.

Tuzet, O. \& Manier, J.-F. 1955. Etude des Trichomycètes de l'intestin des larves de Simulium eguinum Linné récoltés aux Eyzies (Dordogne). Annales des Sciences Naturelles Zoologie, Série 11, 17: 55-62.

Ustinova, I., Krienitz, L. \& Huss, V.A.R. 2000. Hyaloraphidium curvatum is not a green alga, but a lower fungus; Amoebidium parasiticum is not a fungus, but a member of the DRIPS. Protist 151: 253-262.

Valle, L.G. 2004. Tricomicets Ibèrics. Universitat Autònoma de Barcelona, Dept. Biol. Animal Vegetal i Ecologia, Unitat Botànica. Bellaterra, Tesi doctoral inèdita. 324 pp.

Valle, L.G. 2006. Asellariales (Trichomycetes) from the Iberian Peninsula. Fungal Diversity 21: 167-179.

Valle, L.G. 2007. New species and summary of Iberian Harpellales. Mycologia 99: 442-455.

Valle, L.G. \& Santamaria, S. 2004a. The genus Smittium (Trichomycetes, Harpellales) in the Iberian Peninsula. Mycologia 96(3): 682-700.

Valle, L.G. \& Santamaria, S. 2004. Bojamyces transfuga sp. nov. and new records of Trichomycetes from mayfly larvae in Spain. Mycologia 96: 1386-1392.

White, M.M., Cafaro, M. J. \& Lichtwardt, R. W. 2000. Arthropod gut fungi from Puerto Rico and summary of tropical Trichomycetes worldwide. Caribbean Journal of Science 36: 210-220

White, M.M. \& Lichtwardt, R.W. 2004. Fungal symbionts (Harpellales) in Norwegian aquatic insect larvae. Mycologia 96: 891-910.

White, M.M., James, T.Y., O’Donnel, K., Cafaro, M.J., Tanabe, Y. \& Sugiyama, J. 2006a. Phylogeny of the Zygomycota based on nuclear ribosomal sequence data. Mycologia 98: 872-884.

White, M.M., Lichtwardt, R.W. \& Colbo, M.H. 2006b. Confirmation and identification of parasitic stages of obligate endobionts (Harpellales) in blackflies (Simuliidae) by means of rRNA sequence data. Mycological Research 110: 1070-1079.

White, M., Siri, A. \& Lichtwardt, R.W. 2006c. Trichomycete insect symbionts in Great Smoky Mountains National Park and vicinity. Mycologia 98:333-352

Williams, M.C. \& Lichtwardt, R.W. 1990. Trichomycete gut fungi in New Zealand aquatic insect larvae. Canadian Journal of Botany 68: 1045-1056.

Williams, M.C. \& Lichtwardt, R.W. 1993. A new monotypic fungal genus, Allantomyces and a new species of Legeriomyces (Trichomycetes, Harpellales) in the hindgut of a Western Australian mayfly nymph (Tasmanocoenis sp.). Canadian Journal of Botany 71: 1109-1113.

Yeboah, D.O., Undeen, A.H. \& Colbo, M.H. 1984. Phycomycetes parasitizing the ovaries of blackflies (Simuliidae). Journal of Invertebrate Pathology. 43: 363-373. 